\title{
Review on: \\ The Role of Improving Soil Carbon Sequestration to Mitigate Global Climatic Change and Optimize Biogeochemical Cycle of Carbon
}

\author{
Dejene Matiyas \\ Ethiopian Institute of Agricultural Research, Holeta Research Center, PO box 31, Natural Resources Research \\ Directorate. Holeta, Ethiopia
}

\begin{abstract}
The current climatic change issue be coming vital concerns of every sector as far as it related to the efficiency and wellbeing of every sectors globally. Mean annual max and min temperature of Earth's becomes harsh for life on it due to various effects on greenhouse gases concentration triggered from natural and anthropic causes. Soil can be mentioned as a major contributor both as a source and/or sink to manipulate the atmospheric greenhouse gas concentration. Agricultural soil management practice should be considered as a tool to maximize the drawdown of carbon from atmosphere. Soil Carbone sequestration can be optimized through different land management practices which can enhance soil carbon sequestration through increasing the rates of organic matter input, partitioning carbon to longer-lived pools, increasing the longevity of all or selected carbon pools. Different methods of agricultural management use one or more of these pathways to enhance carbon sequestration. Maintaining soil $\mathrm{pH}$ at neutral or higher levels also enhance chemical stability in the form of biochemical recalcitrance, physicochemical protection, or both which increases the rate of humic compound formation and decreases the rate of mineralization, resulting in increased soil organic carbon. Conservation practices and money more others agricultural practices which minimize the Carbone emission from the soil and even trapping the atmospheric Carbone and change it to soil Carbone pool as chelates were contribute significant role in global climatic change mitigation efforts.
\end{abstract}

Keywords: Greenhouse gas, atmosphere, soil, carbon sequestration, humic compound.

DOI: $10.7176 / \mathrm{JNSR} / 9-7-02$

Publication date: April $30^{\text {th }} 2019$

\section{Introduction}

Climatic change due to destructive effects of anthropogenic activities becoming a major concern as it causes unpredictable and harsh environmental outcomes. The greenhouse gases concentration in the atmosphere have increasing in alarming rate since the beginning of the Industrial Revolution. The most important greenhouse gases which related to global temperature change are $\mathrm{CO}_{2}, \mathrm{CH}_{4}$ and $\mathrm{N}_{2} \mathrm{O}$. Recent reports from the Intergovernmental Panel on Climate Change (IPCC) suggest that even if substantial reductions in anthropogenic carbon emissions are achieved in the near future, efforts to sequester previously emitted carbon will be necessary to ensure safe levels of atmospheric carbon and to mitigate climate change (Smith et al. 2014).

Soils are among the planet's largest reservoirs of carbon and hold potential for expanded carbon sequestration, and thus provide a prospective way of mitigating the increasing atmospheric concentration of $\mathrm{CO}_{2}$ (FAO 2001). Carbon sequestration on agricultural lands is possible through a range of soil management strategies and could be substantial with widespread implementation (Daniel 2015). Sequestration of historic carbon emissions is now essential as mitigation alone is unlikely to stabilize our atmosphere. There are several management strategies for drawing carbon out of the atmosphere and holding it in the soil. These strategies vary in effectiveness across different factors like climates, soil types, and geographies (Diana et al. 2013). There are still several arguments about the durability of sequestration in soil and about the precise conditions that increases drawdown of carbon emissions. Research on sequestration has focused primarily on Carbon Capture and Storage (CCS) and reforestation with less attention to the role of soils as carbon sinks.

$\mathrm{CH}_{4}$ and $\mathrm{N}_{2} \mathrm{O}$ have global warming potentials 25 and 298 times higher than $\mathrm{CO}_{2}$, respectively. Most of the $\mathrm{N}_{2} \mathrm{O}$ emissions take place in soils and are related with agricultural activities which is mots dominantly manipulated by anthropic factors (Denman et al. 2007). The $\mathrm{N}_{2} \mathrm{O}$ formation in the soil occurs mainly through nitrification and denitrification processes, which are influenced by soil factors. Those factors related to soil could be easily altered by different soil management practices (Dinesh 2013), therefore understanding the processes of $\mathrm{N}_{2} \mathrm{O}$ formation in soils and the factors influencing these emissions is fundamental to develop efficient strategies to reduce those important greenhouse gas emission in agricultural soils.

Soils also have the potential to sequester carbon from the atmosphere with proper management. Based on global estimates of historic carbon stocks and projections of rising emissions, soil's usefulness as a carbon sink and drawdown solution appears essential (Lal 2008). Since over one third of arable land is in agriculture globally 
(World Bank 2015), finding ways to increase soil carbon in agricultural systems will be a major component of using soils as a sink. A number of agricultural management strategies appear to sequester soil carbon by increasing carbon inputs to the soil and enhancing various soil processes that protect carbon from microbial turnover. Uncertainties about the extent and permanence of carbon sequestration in these systems do still remain, but existing evidence is sufficient to warrant a greater global focus on agricultural soils as a potential climate stability wedge and drawdown solution. Furthermore, the ancillary benefits of increasing soil carbon, including improvements to soil structure, fertility, and water-holding capacity, outweigh potential costs. The objective of these review paper is to investigate and discus the most effective and recent approaches to eliminate the greenhouse gas effects on the current climatic change specially focused on the carbon sequestration on agricultural soil as a major contributor through the basics of soil carbon, how it can be sequestered, management strategies that appear to show promise, and the debate about the potential of agricultural soils to be a climate stability wedge.

\section{Greenhouse Gases and Their Role in Global Climate Change}

A greenhouse gas is a gas in an atmosphere that absorbs and emits radiation within the thermal infrared range of electromagnetic spectrum emitted by Earth. One third of the solar radiation that intercepts the outer atmosphere is bounced back to space. The remaining two thirds pass through the atmosphere and are absorbed by the Earth's surface and by the atmosphere itself. Then, the surface emits back long wave radiation in the form of infrared rays. A great amount of this energy is absorbed by the atmosphere and re-emitted to the Earth's surface. This process is known as greenhouse effect (Le Treut et al. 2007). The primary greenhouse gases in Earth's atmosphere in order, the most abundant greenhouse gases in Earth's atmosphere are water vapor $\left(\mathrm{H}_{2} \mathrm{O}\right)$, carbon dioxide $\left(\mathrm{CO}_{2}\right)$, methane $\left(\mathrm{CH}_{4}\right)$, nitrous oxide $\left(\mathrm{N}_{2} \mathrm{O}\right)$, ozone $\left(\mathrm{O}_{3}\right)$, and (three groups of fluorinated gases (sulfur hexafluoride $\left(\mathrm{SF}_{6}\right)$, hydrofluorocarbons (HFCs), and perfluorocarbons (PFCs)), Chlorofluorocarbons (CFCs). Although CFCs are greenhouse gases, CFCs' contribution to ozone depletion rather than by their contribution to global warming. Note that ozone depletion has only a minor role in greenhouse warming though the two processes often are confused. Without greenhouse gases, the average temperature of Earth's surface would be about $-18{ }^{\circ} \mathrm{C}\left(0^{\circ} \mathrm{F}\right)$, rather than the present average of $15^{\circ} \mathrm{C}\left(59^{\circ} \mathrm{F}\right)$. In the Solar System, the atmospheres of Venus, Mars and Titan also contain gases that cause a greenhouse effect.

Atmospheric concentrations of greenhouse gases are determined by the balance between sources (emissions of the gas from human activities and natural systems) and sinks (the removal of the gas from the atmosphere by conversion to a different chemical compound). The proportion of an emission remaining in the atmosphere after a specified time is the "airborne fraction" (AF). The annual airborne fraction is the ratio of the atmospheric increase in a given year to that year's total emissions. Over the last 50 years (1956-2006) the annual airborne fraction for $\mathrm{CO}_{2}$ has been increasing at $0.25 \pm 0.21 \%$ /year.

Human activities since the beginning of the Industrial Revolution (1750) have produced a $40 \%$ increase in the atmospheric concentration of carbon dioxide, from $280 \mathrm{ppm}$ in 1750 to $400 \mathrm{ppm}$ in 2015. This increase has occurred despite the uptake of a large portion of the emissions by various natural "sinks" involved in the carbon cycle. Anthropogenic carbon dioxide $\left(\mathrm{CO}_{2}\right)$ emissions come from combustion of fossil fuels, principally coal, oil, and natural gas, along with deforestation, soil erosion and animal agriculture. It has been estimated that if greenhouse gas emissions continue at the present rate, Earth's surface temperature could exceed historical values as early as 2047, with potentially harmful effects on ecosystems, biodiversity and the livelihoods of people worldwide. Recent estimates suggest that on the current emissions trajectory the Earth could pass a threshold of $2{ }^{\circ} \mathrm{C}$ global warming, which the United Nations' IPCC designated as the upper limit to avoid "dangerous" global warming, by 2036 .

\subsection{Impacts on The Overall Greenhouse Effect}

As studied by Schmidt et al. (2010) on how individual components of the atmosphere contribute to the total greenhouse effect. They estimated that water vapor accounts for about $50 \%$ of Earth's greenhouse effect, with clouds contributing $25 \%$, carbon dioxide $20 \%$, and the minor greenhouse gases and aerosols accounting for the remaining 5\% (Table 1). In the study, the reference model atmosphere is for 1980 conditions. The contribution of each gas to the greenhouse effect is determined by the characteristics of that gas, related to its abundance, and any indirect effects it may cause. For example, the direct radiative effect of a mass of $\mathrm{CH}_{4}$ is 72 times stronger than the same mass of $\mathrm{CO}_{2}$ over a 20 -year time frame but it is present in much smaller concentrations so that its total direct radiative effect is smaller, in part due to its shorter atmospheric lifetime. On the other hand, in addition to its direct radiative impact, methane has a large, indirect radiative effect because it contributes to ozone formation. Shindell et al. (2005) argue that the contribution to climate change from methane is at least double previous estimates as a result of this effect. 
Table 1. The contribution of different major greenhouse gasses for global warming.

\begin{tabular}{|l|c|c|c|}
\hline Compound & Formula & $\begin{array}{c}\text { Concentration in } \\
\text { atmosphere (ppm) }\end{array}$ & $\begin{array}{c}\text { Contribution } \\
\text { (\%) }\end{array}$ \\
\hline Water vapor and clouds & $\mathrm{H}_{2} \mathrm{O}$ & $10-50,000^{(\mathrm{A})}$ & $\mathbf{3 6 - 7 2 \%}$ \\
\hline Carbon dioxide & $\mathrm{CO}_{2}$ & $\sim 400$ & $\mathbf{9 - 2 6 \%}$ \\
\hline Methane & $\mathrm{CH}_{4}$ & $\sim 1.8$ & $\mathbf{4 - 9 \%}$ \\
\hline Ozone & $\mathrm{O}_{3}$ & $2-8^{(\mathrm{B})}$ & $\mathbf{3 - 7 \%}$ \\
\hline
\end{tabular}

Where. Water vapor strongly varies locally, The concentration in stratosphere. About $90 \%$ of the Ozone in Earth's atmosphere is contained in the stratosphere. Source. Schmidt et al. (2010)

When ranked by their direct contribution to the greenhouse effect, the most important are In addition to the main greenhouse gases listed above, other greenhouse gases include sulfur hexafluoride, hydrofluorocarbons and perfluorocarbons (Signor \& Cerri 2013). Some other greenhouse gases are like, nitrogen trifluoride has a high global warming potential (GWP) but is only present in very small quantities. It is not possible to state that a certain gas causes an exact percentage of the greenhouse effect. This is because some of the gases absorb and emit radiation at the same frequencies as others, so that the total greenhouse effect is not simply the sum of the influence of each gas (Olson et al. 2014). The higher ends of the ranges quoted are for each gas alone; the lower ends account for overlaps with the other gases. In addition, some gases such as methane are known to have large indirect effects that are still being quantified.

Atmospheric lifetime of GHG is important aside from water vapor, which has a residence time of about nine days, major greenhouse gases are well mixed and take many years to leave the atmosphere (Daniel 2015). Although it is not easy to know with precision how long it takes greenhouse gases to leave the atmosphere, there are different methods of estimates.

\subsection{Removal of GHG from the atmosphere ("sinks")}

The concentration of greenhouse gases in the atmosphere is altered in its composition and quantity due to natural and anthropic factors which might change its effect in manipulating the Earths climatic condition. Those GHG altering factors might be act like sink or sources. (Schmidt et al. 2010).

Natural processes: Greenhouse gases can be removed from the atmosphere by various processes, as a consequence of:

- $\quad$ Physical change (condensation and precipitation remove water vapor from the atmosphere).

- Chemical reaction within the atmosphere. For example, methane is oxidized by reaction with naturally occurring hydroxyl radical, $\mathrm{OH}$ and degraded to $\mathrm{CO}_{2}$ and water vapor $\left(\mathrm{CO}_{2}\right.$ from the oxidation of methane is not included in the methane Global warming potential). Other chemical reactions include solution and solid phase chemistry occurring in atmospheric aerosols.

- Physical exchange between the atmosphere and the other compartments of the planet. An example is the mixing of atmospheric gases into the oceans.

- Chemical change at the interface between the atmosphere and the other compartments of the planet. This is the case for $\mathrm{CO}_{2}$, which is reduced by photosynthesis of plants, and which, after dissolving in the oceans, reacts to form carbonic acid and bicarbonate and carbonate ions (see ocean acidification).

- Photochemical change Halocarbons are dissociated by UV light releasing $\mathrm{Cl}$ and $\mathrm{F}$ as free radicals in the stratosphere with harmful effects on ozone (halocarbons are generally too stable to disappear by chemical reaction in the atmosphere).

\section{Negative emissions}

A number of technologies remove greenhouse gases emissions from the atmosphere. Most widely analyzed are those that remove carbon dioxide from the atmosphere, either to geologic formations such as bio-energy with carbon capture and storage and carbon dioxide air capture, or to the soil as in the case with biochar. The IPCC has pointed out that many long-term climate scenario models require large-scale manmade negative emissions to avoid serious climate change.

\section{Impacts of Agriculture in Non- $\mathrm{CO}_{2}$ Greenhouse Gas Emission}

Agricultural activities contribute directly to emissions (source) of greenhouse gases through a variety of processes. Changes in the concentration of GHG, mainly carbon dioxide $\left(\mathrm{CO}_{2}\right)$, methane $\left(\mathrm{CH}_{4}\right)$ and nitrous oxide $\left(\mathrm{N}_{2} \mathrm{O}\right)$, have occurred in the past years and have been related to the increase in global temperature. Among those gases, $\mathrm{N}_{2} \mathrm{O}$ is of great importance because it can stand in the atmosphere for more than 114 years and has a warming potential 298 times greater than $\mathrm{CO}_{2}$. Global $\mathrm{N}_{2} \mathrm{O}$ emissions reach about $17.7 \mathrm{Tg}$ (tera gram) of $\mathrm{N}$ per year, being $6.7 \mathrm{Tg}$ (37.8\%) from anthropic sources. Agricultural soils share $2.8 \mathrm{Tg}$ of $\mathrm{N}$ per year, i.e., $15.3 \%$ of the total amount of 
emissions, or $41.8 \%$ of anthropic emissions (Denman et al. 2007). According to the second Brazilian GHG inventory, $\mathrm{N}_{2} \mathrm{O}$ emissions were about $576 \mathrm{Gg}$, in 2005 , i.e., $7.7 \%$ of the national emissions, which reached 2,200 $\mathrm{Tg}$ of $\mathrm{CO}_{2}$-eq (Brasil 2010).

The agriculture sector was accountable for about $87.2 \%$ of $\mathrm{N}_{2} \mathrm{O}$ emissions, mainly from agricultural soils and animal waste management (Cerri et al. 2009). The greenhouse gases concentration in the atmosphere have significantly increased since the beginning of the Industrial Revolution. Most of the $\mathrm{N}_{2} \mathrm{O}$ emissions take place in soils and are related with agricultural activities. From the total non-CO2 emissions of agriculture sector, $\mathrm{N}_{2} \mathrm{O}$ emission from soils and $\mathrm{CH}_{4}$ emission from enteric fermentation account for $38 \%$ and $32 \%$, respectively. Biomass burning, rice agriculture, and manure management account for $12 \%, 11 \%$, and $7 \%$ of the emissions, respectively (EPA 2006).

Several concurrent processes are responsible for nitrogen gases emissions in agricultural soils (Bockman \& Olfs 1998). Most of the $\mathrm{N}_{2} \mathrm{O}$ is produced through the biological processes of nitrification and denitrification. Autotrophic aerobic nitrification (by ammonia oxidizing bacteria and nitrite-oxidizing bacteria) and anaerobic denitrification, mediated by denitrifying bacteria, are the main microbial processes in the nitrogen cycle in the soil. Other microorganisms are involved in nitrification and denitrification processes: anammox bacteria can convert $\mathrm{NH}_{4}{ }^{+}$and $\mathrm{NO}_{2}{ }^{-}$into $\mathrm{N}_{2}$, under anaerobic conditions, while some fungi can produce $\mathrm{N}_{2}$ and $\mathrm{N}_{2} \mathrm{O}$ by denitrification and code nitrification, and archeae mediate nitrification in marine ecosystems and are capable of promoting denitrification in soils (Hayatsu et al. 2008)

A small fraction of $\mathrm{N}_{2} \mathrm{O}$ is produced in non-biological processes: the chemical decomposition of nitrite (chemi-denitrification) and hydroxylamine oxidation $\left(\mathrm{NH}_{2} \mathrm{OH}\right)$. Chemi-denitrification is the decomposition of $\mathrm{NO}_{2}{ }^{-}$that occurs in neutral and acidic soils, causing volatilization and fixation of $\mathrm{NO}_{2}^{-}$in the soil organic matter (Bremner 1997). The amount of $\mathrm{N}_{2} \mathrm{O}$ produced this way is almost negligible. Hydroxylamine is an intermediate compound in the oxidation of $\mathrm{NH}_{4}{ }^{+}$to $\mathrm{NO}_{3}{ }^{-}$that can produce much more $\mathrm{N}_{2} \mathrm{O}$ than the chemi-denitrification process. In neutral and acidic soils, $\mathrm{N}_{2} \mathrm{O}$ is the main product of the $\mathrm{NH}_{2} \mathrm{OH}$ oxidation, due to its reaction with $\mathrm{Mn}$ and $\mathrm{Fe}$, while in calcareous soils ( $\mathrm{pH}$ from 7.8 to 8.2) the $\mathrm{NH}_{2} \mathrm{OH}$ reacts with $\mathrm{CaCO}_{3}$ and the main product is $\mathrm{N}_{2}$ (Bremner et al. 1980). The treatment, storage, and transportation of livestock manure can produce anthropogenic $\mathrm{CH}_{4}$ and $\mathrm{N}_{2} \mathrm{O}$ emissions. Methane is produced by the anaerobic decomposition of manure. When manure is stored or treated in systems that promote anaerobic conditions (e.g., as a liquid/slurry in lagoons, ponds, tanks, or pits), the decomposition of the volatile solids component in the manure tends to produce $\mathrm{CH}_{4}$. When manure is handled as a solid (e.g., in stacks or dry lots) or deposited on pasture, range, or paddock lands, it tends to decompose aerobically and produce little or no $\mathrm{CH}_{4}$. Ambient temperature, moisture, and manure storage or residency time affect the amount of $\mathrm{CH}_{4}$ produced because they influence the growth of the bacteria responsible for $\mathrm{CH}_{4}$ formation.

For non-liquid-based manure systems, moist conditions (which are a function of rainfall and humidity) can promote $\mathrm{CH}_{4}$ production. Manure composition, which varies by animal diet, growth rate, and type, including the animal's digestive system, also affects the amount of $\mathrm{CH}_{4}$ produced. In general, the greater the energy contents of the feed, the greater the potential for $\mathrm{CH}_{4}$ emissions. However, some higher-energy feeds also are more digestible than lower quality forages, which can result in less overall waste excreted from the animal (Signor \& Cerri 2013). The production of direct $\mathrm{N}_{2} \mathrm{O}$ emissions from organic matter depends on the composition of the crop residue, manure and urine, the type of bacteria involved in the decomposition process, and the amount of oxygen and liquid in the OM. For direct $\mathrm{N}_{2} \mathrm{O}$ emissions to occur, the OM must first be handled aerobically where ammonia $\left(\mathrm{NH}_{3}\right)$ or organic $\mathrm{N}$ is converted to nitrates and nitrites though nitrification process, and then handled anaerobically where the nitrates and nitrites are reduced to dinitrogen gas $\left(\mathrm{N}_{2}\right)$, with intermediate production of $\mathrm{N}_{2} \mathrm{O}$ and nitric oxide (NO) denitrification (Groffman et al. 2000). These emissions are most likely to occur in dry manure handling systems that have aerobic conditions, but that also contain pockets of anaerobic conditions due to saturation. A very small portion of the total $\mathrm{N}$ excreted is expected to convert to $\mathrm{N}_{2} \mathrm{O}$ in the waste management system (WMS). Indirect $\mathrm{N}_{2} \mathrm{O}$ emissions are produced when nitrogen is lost from the system through volatilization (as $\mathrm{NH}_{3}$ or $\mathrm{NO}_{\mathrm{x}}$ ) or through runoff and leaching. The vast majority of volatilization losses from these operations are $\mathrm{NH}_{3}$. Although there are also some small losses of $\mathrm{NO}_{\mathrm{x}}$, there are no quantified estimates available for use, so losses due to volatilization are only based on $\mathrm{NH}_{3}$ loss factors. Runoff losses would be expected from operations that store manure in a manner that is exposed to weather. Runoff losses are also specific to the type of animal housed on the operation due to differences in manure characteristics (Green et al. 2011). Little information is known about leaching from manure management systems as most research focuses on leaching from land application systems. Since leaching losses are expected to be minimal, leaching losses are coupled with runoff losses and the runoff/leaching estimate not account for any leaching losses Use of liquid manure management systems have higher potential $\mathrm{CH}_{4}$ emissions than dry systems.

\section{Biogeochemical Carbon Cycle and Climate Change}

The nutrient cycle describes how nutrients move from the physical environment (soil, aquatic and atmospheric systems) into living organisms and subsequently recycled back to the physical environment accordingly carbon is 
constantly cycling between different global carbon pools as it changes molecular forms. Photosynthesis and the subsequent use of its byproducts by other organisms' cycles carbon between the atmosphere into forests, soils, and oceans, while human energy consumption cycles carbon from fossil fuel pools to the atmosphere (Wikipedia). As carbon flows between them, each of these different pools has the capacity to be either a source or a sink. Carbon sinks are pools that accumulate more carbon than they release, while carbon sources release more carbon than they accumulate. Understanding source/sink dynamics and how to optimize the capacity of sinks to draw and keep carbon out of the atmosphere is crucial to reversing anthropogenic climate change. Currently the atmosphere and ocean have too much carbon while soils have lost carbon at an alarming rate due to development, conversion of native grasslands and forests to cropland, and agricultural practices that decrease soil organic matter (Eugster \& Buchmann 2011). Estimates of the precise size and annual net change in carbon pools vary, but the relative sizes of each primary planetary pool of carbon - oceans/aquatic systems, vegetation, and soils are well understood. The atmospheric carbon pool is connected to the oceanic pool, which absorbs $92.3 \mathrm{Pg} \mathrm{yr}^{-1}$ and releases $90 \mathrm{Pg} \mathrm{yr}^{-1} \mathrm{with}$ a net positive balance of $2.3 \mathrm{Pg} \mathrm{C} \mathrm{yr}^{-1}$. The oceanic pool will absorb approximately $5 \mathrm{Pg} \mathrm{C} \mathrm{yr}^{-1}$ by 2100 (Orr et al. 2001). The total dissolved inorganic $\mathrm{C}$ in the oceans is approximately 59 times that of the atmospheric pool. On the scales of millennia, the oceans determine the atmospheric $\mathrm{CO}_{2}$ concentration, not vice versa (Falkowski et al. 2000).

Atmospheric $\mathrm{C}$ was approximately $280 \mathrm{ppm}$ in the preindustrial era and had increased to $370 \mathrm{ppm}$ by 2000 (Lal 2001). To stabilize future atmospheric $C$ concentrations at $550 \mathrm{ppm}(\sim 2$ times the preindustrial level $)$ will require an annual reduction in worldwide $\mathrm{CO} 2$ emissions from the projected level of 21 to 7 billion tons (measured as C) by the year 2100 (Hileman 1999). Over the past 150 years, the amount of $\mathrm{C}$ in the atmosphere, from greenhouse gases such as $\mathrm{CO}_{2}, \mathrm{CH}_{4}$, and $\mathrm{N}_{2} \mathrm{O}$, has increased by $30 \%$. The increased levels of gases, particularly $\mathrm{CO} 2$, are strongly linked to global warming. The increased levels of greenhouse gases are largely due to high levels of fossil fuel (oil, coal) combustion, deforestation, wildfires, and cultivation of land. There are a number of ways to reduce atmospheric $\mathrm{CO}_{2}$. These include the use of technology to develop energy-efficient fuels and the use of non-C energy sources such as solar, wind, water, and nuclear energy.

Another way to reduce atmospheric $\mathrm{CO}_{2}$ is by carbon sequestration. Carbon sequestration is the long-term storage of $\mathrm{C}$ in oceans, soils, vegetation (especially forests), and geologic formations. The global carbon pools and the $\mathrm{C}$ cycle are shown in Fig. The cycle is composed of both inputs (pools) and outputs (fluxes) in the environment. The ocean pool is estimated at 38,000 Pg (peta grams $=1 * 10^{15} \mathrm{~g}=1$ billion metric tons), the geologic pool at $5000 \mathrm{Pg}$, the soil organic C (SOC) pool, stored primarily in SOM, at 1500 (up to $1 \mathrm{~m} \mathrm{depth}$ ) $2400 \mathrm{Pg}$ (up to $2 \mathrm{~m}$ depth), (Fig 1) the atmospheric pool at $750 \mathrm{Pg}$, and the biotic pool (e.g., plants) at $560 \mathrm{Pg}$ (Lal 2001). The atmospheric $\mathrm{C}$ pool has been increasing at the expense of the geological pool due to fossil fuel emission, the biotic pool due to deforestation and wildfires, and the soil pool due to cultivation and other anthropogenic disturbances (Lal 2001).

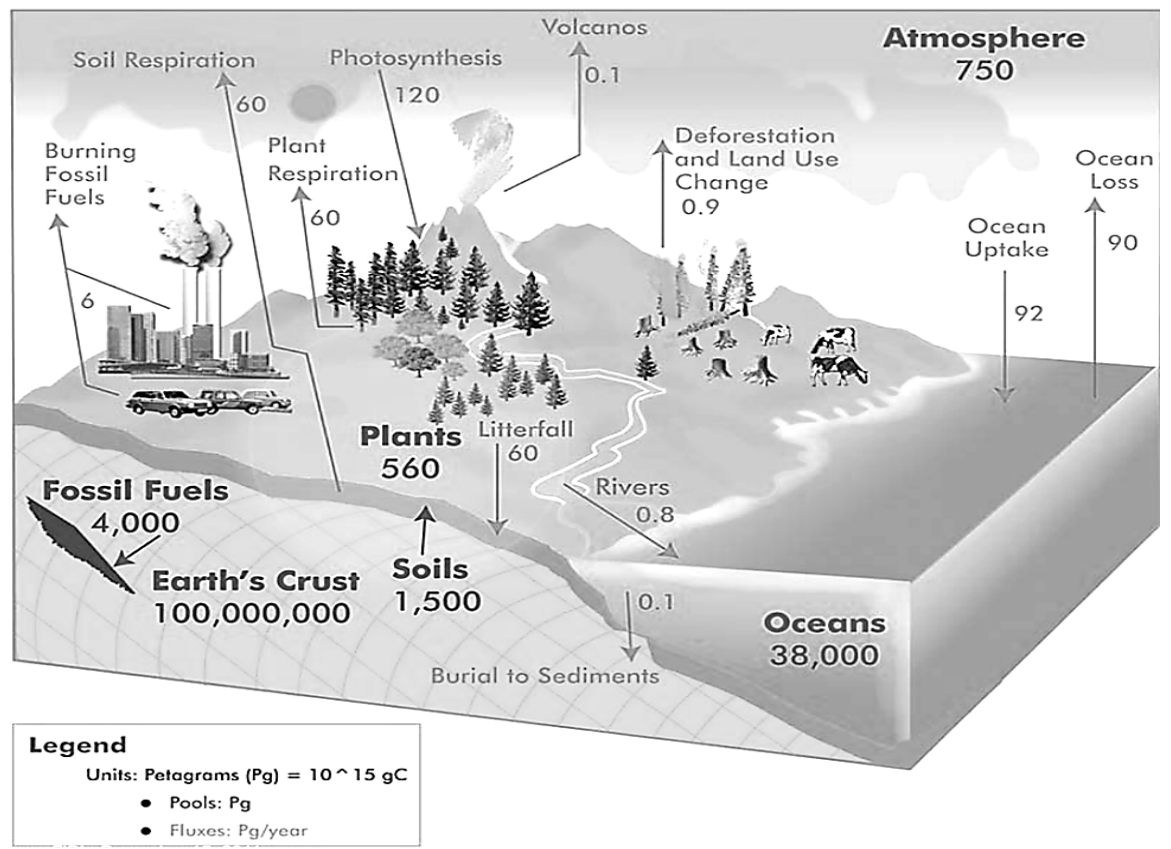

Figure 1. Different global carbon pools and their contribution for atmospheric carbon dioxide emission. Source: Eugster \& Buchmann (2011).

It has been estimated that land use changes and agriculture play an important role in emission of $\mathrm{CO}_{2}, \mathrm{CH}_{4}$, and $\mathrm{N}_{2} \mathrm{O}$ and account for $20 \%$ of the increase in radioactive force (Lal 2001). The SOC pool, assuming an average 
content of $2400 \mathrm{Pg}$ to $2 \mathrm{~m}$ depth, is 3.2 times the atmospheric pool and 4.4 times the biotic pool. Soils contain about $75 \%$ of the $\mathrm{C}$ pool on land, three times more than stored in living plants and animals. In addition to the SOC pool there is a soil inorganic carbon (SIC) pool that ranges from $695-748 \mathrm{Pg} \mathrm{of} \mathrm{CO}_{2-3}$, and is most important in subsurface horizons of arid and semiarid soils (Baties 1996). The source of the SIC pool is primary (lithogenic) carbonates and pedogenic $2^{\text {ry }}$ carbonates, the latter being more important in $\mathrm{C}$ sequestration. The pedogenic carbonates are formed when $\mathrm{H}_{2} \mathrm{CO}_{3}$ chemically reacts with cations in the Earths crest upper portion of the soil horizon like $\mathrm{Ca}^{2+}$ and/or $\mathrm{Mg}^{2+}$ in the soil solution and leached in lower soil horizons via irrigation. The rate of SIC sequestration by this mechanism may be 0.25 to $1 \mathrm{Mg} \mathrm{C} \mathrm{ha}^{-1}$ year $^{-1}$ (Wilks \& Wilby 1999). Accordingly, the role that soils, particularly SOM, play in the global $\mathrm{C}$ cycle is immense; both in serving as a pool in sequestering $\mathrm{C}$ and also as a flux in releasing $\mathrm{C}$. Land use and crop and soil management have drastic effects on the level of the SOC pool, and thus, C sequestration. Declines in the SOC pool are due to (a) mineralization of soil organic carbon, (b) transport by soil erosion processes, and (c) leaching into subsoil or groundwater. The rate of SOC loss due to conversion from natural to agricultural ecosystems, particularly cultivation which enhances soil respiration and mineralization and decomposition of SOC, is more significant in tropical than in temperate region soils, is higher from cropland than from pastureland, and is higher from soils with high SOC levels than with low initial levels (Mann 1986).

The loss of SOC due to cultivation may be as high as $60-80 \mathrm{Mg} \mathrm{C} \mathrm{ha}^{-1}$. Schlesinger (1999) estimated the loss of $\mathrm{C}$ from cultivated soils as large as $0.8 * 10^{15} \mathrm{~g} \mathrm{C}$ year $^{-1}$. Some soils may lose the SOC pool at a rate of $2-12 \%$ year $^{-1}$, with a cumulative decrease of $50-70 \%$ of the original pool (Lal 2001). The use of limited cultivation (tillage) such as no-tillage can dramatically reduce $\mathrm{C}$ losses from soils by reducing mineralization and erosion, and promoting $\mathrm{C}$ sequestration. It has been estimated that extensive use of no tillage in crop production could alone serve as a sink for 277 to $452 * 10^{12} \mathrm{~g} \mathrm{C}$, about $1 \%$ of the fossil fuel emissions during the next 30 years (Kern 1994). Cover crops such as legumes and crop rotation can also enhance $\mathrm{C}$ sequestration.

Robertson et al. (2000) measured $\mathrm{N}_{2} \mathrm{O}$ production, $\mathrm{CH}_{4}$ oxidation, and soil $\mathrm{C}$ sequestration in cropped and unmanaged ecosystems in Midwestern USA soils. Except for a conventionally managed system conventional tillage and chemical inputs), all cropping systems sequestered soil $\mathrm{C}$. The no-till system (conventional chemical inputs) accumulated $30 \mathrm{~g} \mathrm{C} \mathrm{m}^{-2}$ year $^{-1}$ and the organic-based systems (reduced chemical inputs and organic with no chemical inputs), which included a winter legume cover crop, sequestered $8-11 \mathrm{~g} \mathrm{C} \mathrm{m}^{-2}$ year $^{-1}$. Despite the gains in the soil $\mathrm{C}$ pool and thus, $\mathrm{C}$ sequestration, resulting from no-tillage agriculture and cover crops, these must be balanced by considering $\mathrm{CO}_{2}$ fluxes due to manufacture of applied inorganic $\mathrm{N}$ fertilizers and irrigation of crops (Schlesinger 1999). $\mathrm{CO}_{2}$ is produced in $\mathrm{N}$ fertilizer production ( 0.375 moles of $\mathrm{C}$ per mole of $\mathrm{N}$ produced $)$, and fossil fuels are used in pumping irrigation water. Additionally, the ground waters of arid regions can contain as much as $1 \%$ dissolved $\mathrm{Ca}$ and $\mathrm{CO}_{2}$ vs $0.036 \%$ in the atmosphere. When such waters are applied to arid soils $\mathrm{CO}_{2}$ is released to the atmosphere.

$\left(\mathrm{Ca}^{2+}+2 \mathrm{HCO}_{3}{ }^{-} \rightarrow \mathrm{CaCO} \downarrow \downarrow+\mathrm{H}_{2} \mathrm{O}+\mathrm{CO}_{2} \uparrow\right)$.

Carbon sequestration can also be significantly enhanced by restoring soils degraded by erosion, desertification, salinity, and mining operations. Such practices as improving soil fertility by adding inorganic and organic fertilizer amendments, increasing biomass and decreasing erosion by establishing cover crops and crop rotations, implementing limited and no-tillage systems, and irrigating can increase C sequestration by 0.1 to $42 \mathrm{Mg} \mathrm{ha}^{-1}$ in terms of total SOC and from 0.1 to $4.5 \%$ in SOC content (Lal 2001).

\section{The Role of Soils in Carbon Sequestration}

Carbon sequestration is the long-term storage of carbon in oceans, soils, vegetation (especially forests), and geologic formations. Although oceans store most of the Earth's carbon, soils contain approximately $75 \%$ of the carbon pool on land which is three times more than the amount stored in living plants and animals. Therefore, soils play a major role in maintaining a balanced global carbon cycle.

The terrestrial carbon cycle soil organic carbon represents the largest reservoir in interaction with the atmosphere and is estimated at about $1500 \mathrm{Pg} \mathrm{C}$ to $1 \mathrm{~m}$ depth (about $2456 \mathrm{Pg} \mathrm{C}$ to $2 \mathrm{~m}$ depth). Inorganic C represents around $1700 \mathrm{Pg}$, but it is captured in more stable forms such as caliches. Vegetation $(650 \mathrm{Pg})$ and the atmosphere $(750 \mathrm{Pg})$ store considerably less $\mathrm{C}$ than soils do. Fluxes between terrestrial or soil organic carbon and the atmosphere are important and can be positive (sequestration) or negative (emission of $\mathrm{CO}_{2}$ ). Historically, wide variations have been noted. Houghton (1995) estimates that emissions corresponding to change in land use (deforestation and increase in pasture and cultivated lands) were around $140 \mathrm{Pg}$ from 1850 to 1990 (from $0.4 \mathrm{Pg}$ $\mathrm{yr}^{-1}$ in 1850 to $1.7 \mathrm{Pg} \mathrm{yr}^{-1}$ in 1990), with a net release to the atmosphere of $25 \mathrm{Pg} \mathrm{C}$.

According to IPCC (2000), the historical loss from agricultural soils was $50 \mathrm{Pg} \mathrm{C}$ over the last half century, which represents $1 / 3$ of the total loss from soil and vegetation. In the past, the development of agriculture was the main cause of the increasing $\mathrm{CO}_{2}$ concentration in the atmosphere, but now the combustion of fossil carbon by industry and transport $\left(6.5 \mathrm{Pg} \mathrm{yr}^{-1}\right)$ represents the main contribution. An important point is that, at present, while deforestation in many tropical areas produces $\mathrm{C}$ emissions estimated at about $1.5 \mathrm{Pg} \mathrm{C}$ per year, elsewhere around 
1.8 to $2 \mathrm{Pg} \mathrm{C}$ per year is accumulating in terrestrial ecosystems. This represents what is called the "missing carbon" in the cycle: a sink that may be mainly situated in the northern part of the northern hemisphere (Schindler 1999). The main factors acting on organic matter evolution concern the vegetation (residue input, plant composition), then climatic factors (temperature/moisture conditions) and soil properties (texture, clay content and mineralogy, acidity), others factors relating to soil fertilization with (N, P, or S), or irrigation, have an effect on the plant production and hence on organic matter content. The rate of SOM mineralization depends mainly on temperature and oxygen availability (drainage), land use, cropping system, soil and crop management (Lal et al. 1995). In a given soil type exposed to a constant practice, a near equilibrium (steady state) SOM content is normally reached after 30 to 50 years (Greenland 2011). In the context of combating global warming and the Kyoto Protocol, an important question is how to create a major, well-quantified carbon sink in agricultural soils worldwide. Such sequestration will be relevant for protocol articles 3.3 and 3.4. It will also have important additional positive effects for agriculture, environment and biodiversity.

\section{Composition of SOM}

The main constituents of SOM are Carbon (52-58\%), Oxygen (34-39\%), Hydrogen (3.3-4.8\%), and Nitrogen (3.7-4.1\%). the elemental composition of HA from several soils is similar. Other prominent elements in SOM are $\mathrm{P}$ and S. Research from Waksman \& Stevens (1930) showed that the $\mathrm{C} / \mathrm{N}$ ratio is around 10. The major organic matter groups are lignin-like compounds and proteins, with other groups, in decreasing quantities, being hemicellulose, cellulose, and ether and alcohol soluble compounds. While most of these constituents are not water soluble, they are soluble in strong bases. SOM consists of non-humic and humic substances.

The non-humic substances have recognizable physical and chemical properties and consist of carbohydrates, proteins, peptides, amino acids, fats, waxes, and low-molecular-weight acids. These compounds are attacked easily by soil microorganisms and persist in the soil only for a brief time. Humic substances can be defined as "a general category of naturally occurring, biogenic, heterogeneous organic substances that can generally be characterized as being yellow to black in color, of high molecular weight (MW), and refractory" (Aiken et al. 1985). They are amorphous, partly aromatic, polyelectrolyte materials that no longer have specific chemical and physical characteristics associated with well-defined organic compounds (Schnitzer \& Schulten 1995). Humic substances can be subdivided into humic acid (HA), fulvic acid (FA), and humin. Definitions of HS are classically based on their solubility in acid or base (Schnitzer \& Khan 1972) as will be discussed later in the section Fractionation of SOM. Several mechanisms for explaining the formation of soil were proposed.

Selman Waksman's classical theory, the so-called lignin theory, was that HS are modified lignins that remain after soil microbial attack (Figure 2). The modified lignins are characterized by a loss of methoxyl $\left(\mathrm{OCH}_{3}\right)$ groups and the presence of o (ortho)-hydroxy phenols and oxidation of aliphatic side chains to form $\mathrm{COOH}$ groups. These lignins undergo more modifications and then result in first HA and then FA. Pathway 1, which is not considered significant, assumes that HS form from sugars (Stevenson 1982). The contemporary view of HS genesis is the polyphenol theory that involves quinones. In pathway 3 lignin is an important component of HS creation, but phenolic aldehydes and acids released from lignin during microbial attack enzymatically are altered to quinones, which polymerize in the absence or presence of amino compounds to form humic-like macromolecules. Pathway 2 is analogous to pathway 3 except the polyphenols are microbially synthesized from non-lignin $\mathrm{C}$ sources, e.g., cellulose, and oxidized by enzymes to quinones and then to HS (Stevenson 1982). While the polyphenol theory is currently in vogue to explain the creation of HS, all four pathways may occur in all soils. However, one pathway is usually prominent. For example, pathway 4, the lignin pathway, may be primary in poorly drained soils while the polyphenol pathways two \& three may predominate in forest or drained soils (Stevenson 1982).

Because of burning fossil fuels, cultivation and draining of grasslands and wetlands, deforestation, and landuse conversions, there has been increased interest in developing methods to sequester atmospheric $\mathrm{CO}_{2}$ (Sundermeier et al. 2005; Baker et al. 2007; Lal 2009). In agricultural land areas, NT systems have been proposed as an alternative to replace intensive tillage systems such as MP and CP as a way to sequester SOC (Ogle et al. 2012). 


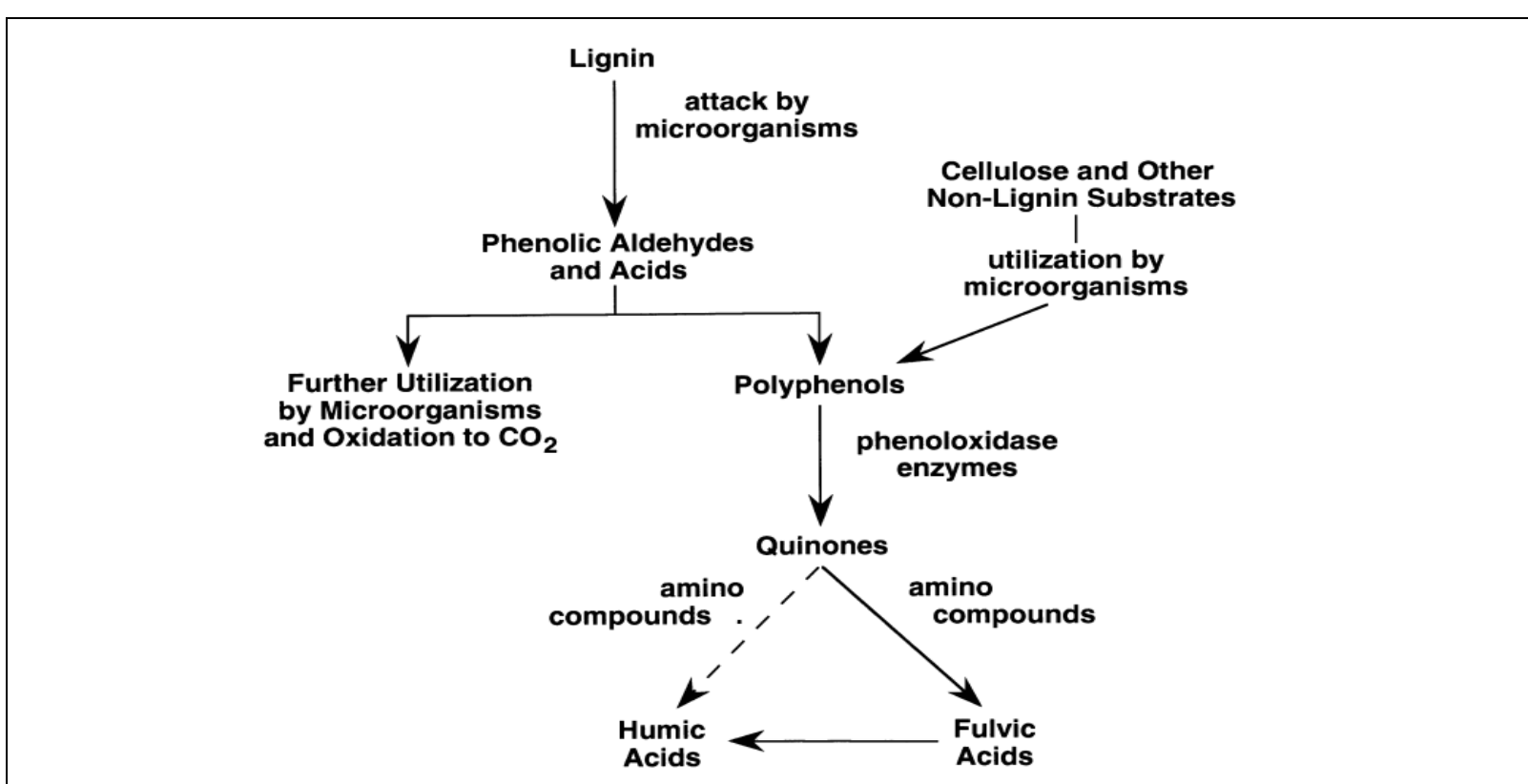

Figure 2. Schematic representation of the polyphenol theory of humus formation. From F. J. Stevenson, "Humus Chemistry." Source: John Wiley \& Sons (1982).

Several researchers (Liebig et al. 2005; Lal et al. 1998; Johnson et al. 2005; Kumar et al. 2012) have recommended that converting from MP or CP systems to NT has a large potential for SOC sequestration, but NT does affect the distribution of SOC within the soil profile (Baker et al. 2007; Luo et al. 2010; Vanden Bygaart et al. 2003; Sundermeier et al. 2005; Ogle et al. 2012). When NT, CP, and MP are under a non-steady state (Olson 2010) all three tillage systems may fail to sequester a significant amount of SOC. Conservation tillage and NT systems along with crop rotation have been implemented to maximize soil C storage or SOC sequestration. Lal et al. (1998) suggested that conversion of a conventional system to NT could result in a $0.50 \mathrm{Mg}$ or $106 \mathrm{~g} \mathrm{C} \mathrm{ha}^{-1} \mathrm{yr}^{-}$ ${ }^{1}$ sequestration rate, and West \& Post (2002) researched on conversion of plow tillage (PT) to NT can sequester $0.57 \mathrm{Mg} \mathrm{C} \mathrm{ha}^{-1} \mathrm{yr}^{-1}$ over 15 to $22 \mathrm{yr}$. Results from another study suggested that a NT system sequestered SOC in the top 0 to $20 \mathrm{~cm}$ layer at $0.19 \mathrm{Mg} \mathrm{Cha}^{-1} \mathrm{yr}^{-1}$ for Hoytville soil and $0.17 \mathrm{Mg} \mathrm{Cha}^{-1} \mathrm{yr}^{-1}$ for Wooster soil in Ohio, USA (Kumar et al. 2012).

Research results reported specific regional SOC sequestration rates were apparently determined based on many comparison studies within each region (Christopher et al. 2009) with the SOC concentration measured at the end of the tillage study and it was reported that SOC stock was greater in soil under NT than those under MP. These findings of SOC sequestration were based on results of paired comparisons of NT to other conventional tillage systems with no pretreatments baseline SOC concentration measurement and assuming that conventional system baseline was at steady state (Christopher et al. 2009). Changes in SOC concentration with changes in management can either be related to enhanced tillage disturbance or changes in $\mathrm{C}$ inputs. Carbon inputs from outside a land unit, such as animal waste or other $\mathrm{C}$ sources, are considered to be a redistribution of $\mathrm{C}$ already in storage and from external sources and not sequestered SOC. Carbon rich amendments need to be accounted for when they are applied to the land unit.

\section{Measurement Methods of Soil Carbon Stocks}

Organic matter that is above the soil surface in the litter layer which is not decomposed and/or partly decomposed is not considered in the assessment of soil carbon stocks. For cultivated soils, this means that plant or crop residues are considered as a transitory phase. However, crop residues, cover crops or mulch are important parts of the agroecosystem. Similarly, forest litter can amount to some 8 or $9 \mathrm{~kg} \mathrm{C} \mathrm{m}^{-2}$ for temperate forests (Dupouey et al. 1999), 5 or $6 \mathrm{~kg} \mathrm{C} \mathrm{m-2} \mathrm{a} \mathrm{tropical} \mathrm{forest} \mathrm{on} \mathrm{a} \mathrm{Ferralsol} \mathrm{(Andreux} \mathrm{\&} \mathrm{Choné} \mathrm{1993).} \mathrm{Live} \mathrm{roots} \mathrm{are} \mathrm{considered} \mathrm{as} \mathrm{C} \mathrm{biomass}$ and in grasslands, for example, this compartment can contribute the greater part of soil C. The method most commonly applied is to determine total organic carbon at different depths or globally for one or more horizons and to transform the data, considering the bulk density and stoniness of the soil. Statistics are calculated on different samples to determine $\mathrm{C}$ stocks. The results may be expressed in $\mathrm{kg} \mathrm{m}^{-2}, \mathrm{t} \mathrm{ha}^{-1}$ or $\mathrm{Gt}(\mathrm{Pg})$ totals over specified areas and depth ranges. The scale can be the site or plot, the watershed, the region, a specific country or continent or the agroecological zone (FAO/IIASA 1999). The spatial extension is made using digitized maps for the different soil units considered. The number of soil profile analyses used is very important and until now there has been a lack of good, site-referenced data.

With respect to soil carbon stocks at world scale, there are three important references. Sombroek et al. (1993), 
used the FAO/UNESCO Soil Map of the World (at 1:5 000000 scale) and about 400 soil profiles, grouped per FAO soil unit, with range and median values for organic carbon content and bulk density for each soil unit. They were able to estimate organic carbon stocks by FAO soil groups and the soil carbon stock of the world. Post et al. 1982, Eswaran et al. 1993, used the US Soil Taxonomy and more profile analyses (close to 16000), with the majority coming from pedons in the USA (WSR-SCS). The total estimate of organic C stock is $1550 \mathrm{Pg}$. More details are given concerning stocks for the different soil suborders or orders, or for the different profile depths. In conclusion, the authors stress in the estimation the importance of considering land use and land management changes.

More recently, Batjes (1996) carried out a revision of the estimate using the Wise database with 4353 profiles (19222 C analyses) with a more representative geographical distribution. This study confirmed a total soil C of about $1500 \mathrm{Pg}$ in the upper horizons $(0-100 \mathrm{~cm})$, but also revealed the presence of important and stable $\mathrm{C}$ stocks at depths between 100 and $200 \mathrm{~cm}$, especially in tropical soils (Table 2), it considered that the general soil information system (FAO/UNESCO 1974) was not completely adapted to enable estimation of changes in soil properties induced by land use changes or other factors (for example, climatic change).

Table 2. Mean carbon content as affected by different soil types in FAO-UNESCO and WRB soil classification systems.

\begin{tabular}{|ll|rrr|}
\hline \multicolumn{2}{|c|}{ Soil unit } & \multicolumn{3}{c|}{ Mean C content $\mathbf{~ k g} / \mathbf{m}^{\mathbf{2}}$} \\
\hline FAO-UNESCO & WRB & $\mathbf{0 ~ - 3 0 ~} \mathbf{~ c m}$ & $\mathbf{0 - 1 0 0 ~} \mathbf{~ m ~}$ & $\mathbf{0 ~ - ~ 2 0 0 ~} \mathbf{~ c m}$ \\
\hline Podzols & Podzols & 13.6 & 24.2 & 59.1 \\
Rendzinas & Leptosols & 13.3 & - & - \\
Lithosols & Leptosols & 3.6 & - & - \\
Chernozems & Chernozems & 6 & 12.5 & 19.6 \\
Nitosols & Nitosols & 4.1 & 8.4 & 11.3 \\
Xerosols & Calcisols/Cambisols & 2 & 4.8 & 8.7 \\
Yermosols & Calcisols/Gypsisols & 1.3 & 3 & 6.6 \\
Ferralsols & Ferralsols & 5.7 & 10.7 & 16.9 \\
Vertisols & Vertisols & 4.5 & 11.1 & 19.1 \\
Andosols & Andosols & 11.4 & 25.4 & 31 \\
\hline
\end{tabular}

Notes: 1:1 correlation with WRB units secures "risky"for some of these units.

Source: FAO - Unesco (1974) and WRB soil units (from Batjes, 1996)

The data presented in Table 2 show the great variation of organic carbon in relation with soil types. Total amounts of $\mathrm{C}$ in soils of arid areas (Xerosols, Yermosols) are low around $7 \mathrm{~kg} \mathrm{~m}^{-2} \mathrm{C}$, compared with soils in the tropics, in the order of 15 to $30 \mathrm{~kg} / \mathrm{m}^{2}$, but these are diverse depending on texture and mineralogy. Soil carbon contents depend on the main long-term factors of soil formation, but can be strongly modified (degraded or improved) by land use changes and land management. Most of the statistical studies on soil $\mathrm{C}$ stocks and distribution are based essentially on soil maps. Recently, similar evaluations have been made in France (Arrouays et al. 1999) which considers both soil types and vegetation cover. Soil C analyses which were available were georeferenced pedological data from the national database and data from a systematic soil monitoring network (16 $\mathrm{x}$ $16 \mathrm{~km}$ ) available at European scale, but only for forest soils. Information from a soil map and a land use map was used to produce simple statistics on carbon stocks in different land uses (with 13 types of uses, according to the Corine Land Cover-definitions) and soil types (with 17 FAO-defined groups of soils). The total number of existing combinations was 138 . The resulting soil carbon map of France allowed an estimate to be made of the carbon stock (3.1 Pg to a depth of $30 \mathrm{~cm}$ ), and also to identify the main controlling factors of the carbon distribution: land use, soil type or other characteristics (climatic, pedologic, etc.).

Other papers have attempted similar combinations between soil type and vegetation (Howard et al. 1995 for Great Britain; Moraes et al. 1998 for Rondônia, Brazil; Van Noordwijk et al. 1997 for the humid forest zones). Both soil and land use data should be used in determining soil carbon stocks. While soil factors are important, as are climatic factors, in explaining carbon storage or pools over long periods of time, changes in vegetation or land use determine the changes in carbon sequestration. The arid zone, which covers $40 \%$ of the global land surface, stocks only $5 \%(100 \mathrm{Pg})$ of the total soil carbon these agro-ecological zones, developed by FAO, can constitute a reference framework to evaluate and monitor soil $\mathrm{C}$ storage in soils.

\section{Soil Management practice to Improve soil carbon sequestration}

Removing $\mathrm{CO}_{2}$ from the atmosphere is only one significant benefit of enhanced carbon storage in soils. Improved soil and water quality, decreased nutrient loss, reduced soil erosion, increased water conservation, and greater crop production may result from increasing the amount of carbon stored in agricultural soils. The impact of tillage disturbance applied to a land unit on SOC concentration has been documented. Land unit crop yield, biomass, and 
residue returned to the soil are usually not significantly different as a result of the tillage treatment (Olson et al. 2013). If the residue returned to the land unit soil is significantly different between tillage treatments and resulted in humus formation increase it could be as a result of SOC sequestration. When the impacts of tillage treatments on SOC sequestration are measured, the $\mathrm{C}$ inputs are often statistically similar for all tillage treatments. Therefore, only the effects of tillage disturbance which does have a significant effect on SOC loss were considered. Balesdent et al. (1990) compared PT with NT and observed that PT practice enhances SOC and N mineralization by incorporating crop residues, disrupting soil aggregates and increasing aeration causing a reduction in SOC and N stocks. Plowing was the primary cause of SOC oxidation and emission of $\mathrm{CO}_{2}$ to the atmosphere (Al-Kaisi 2008). Drainage of poorly drained, nearly level soils (Olson et al. 2002) and well drained, sloping and eroded soils (Olson 2010) often resulted in the accelerated rates of SOC oxidation and emission of $\mathrm{CO}_{2}$. Kern (1994) estimated historical soil $\mathrm{C}$ losses in the top $30 \mathrm{~cm}$ after cultivation for major field crops in the contiguous USA to be $16 \%$ primarily as a result of plowing which caused oxidation of SOC and emissions of $\mathrm{CO}_{2}$ to the atmosphere. The SOC stock of timberland and prairie soils declined with cultivation in North America (Franzluebbers \& Follett 2005). The SOC rate of decline as a result of cultivation was $22 \pm 10 \%$ for the northeast, $34 \pm 24 \%$ for the northwest, no value was reported for the central, $25 \pm 33 \%$ for southwest and $36 \pm 29 \%$ for southeast. Many researchers (Clark et al. 1985; Lal 2003) have reported that accelerated soil erosion exacerbates C emissions. Lal (1995) suggested that $20 \%$ of the $\mathrm{C}$ translocated by erosion may be released eventually as $\mathrm{CO}_{2}$ into the atmosphere, $10 \%$ to transport as dissolved $\mathrm{C}$ in water bodies, and $70 \%$ remains on the landscape often on a lower landscape position. Van Oost et al. (2007) found that the eroded $\mathrm{C}$ gets buried at the bottom of the slope where decomposition rates are slower. According to Baker et al. (2007), this difference in SOC distribution can be attributed to different properties of PT vs. NT soils. In general, NT soils are more compacted with greater bulk density, particularly at the soil surface, than recently plowed soils (Kitur et al. 1993). Furthermore, crop residues left on the soil in NT causes a decrease in soil temperature early in the growing season, which limits root growth (Baker et al. 2007). West and Post (2002) reviewed 137 paired studies, but in the studies considered, SOC concentration was only measured in the top 15 or $30 \mathrm{~cm}$ of soil (Baker et al. 2007). Another review by Vanden Bygaart et al. (2003), however, included studies where SOC concentration was measured to a depth more than $30 \mathrm{~cm}$.

Table 3. Different mechanisms of carbon sequestration in soil their application methods.

\begin{tabular}{|l|l|}
\hline Sequestration Mechanism & Practice \\
\hline Increase input & $\begin{array}{l}\text { Diversified crop rotation, improved cultivars with vigorous return of } \\
\text { crop residue, intensive cropping with various use of inputs, increase crop } \\
\text { productivity, increased use of organic manure, elimination of fallow, } \\
\text { substituting from annual crop to perennials vegetation, agro-forestry } \\
\text { system, improved use of irrigation, greater root biomass, deep placement } \\
\text { of carbon. }\end{array}$ \\
\hline Decrease emissions & $\begin{array}{l}\text { Minimal/zero tillage, control soil erosion, mulch farming, minimize the } \\
\text { use of low grade organic materials as input, reduced bare fallow. }\end{array}$ \\
\hline
\end{tabular}

Improved management of agroecosystems can significantly enhance $\mathrm{C}$ sequestration in soils. Management practices or technologies that increase $\mathrm{C}$ input to the soil or reduce $\mathrm{C}$ emissions, or both, lead to net $\mathrm{C}$ sequestration in soils (Nieder \& Benbi 2008). Increased C input in agroecosystems can be achieved in a number of ways, for example, selection of high-biomass producing crops, residue recycling or residue retention by reduced tillage intensity, application of organic materials (e.g., animal manure, compost, sludge, and green manure), adoption of agroforestry systems, improved nutrient and water management practices, reducing summer or winter fallow, changing from monoculture to rotation cropping, and switching from annual crops to perennial vegetation. Enhancing rotation complexity, for example, changing from monoculture to continuous cropping, changing crop fallow to continuous cropping, or increasing the number of crops in a rotation, can sequester on an average $20 \pm$ $12 \mathrm{~g} \mathrm{C} / \mathrm{m}^{2} /$ year (West \& Post 2002). Forestry and agroforestry have been proposed as a means to sequester $\mathrm{C}$ and reduce GHG emissions. It has been estimated that the application of optimum forestry and agroforestry management practices on 500-800 ha in 12-15 key nations could sequester 1-2 Gt C/year (Winjum et al. 1992). Management techniques, which are successful in providing a net carbon sink in soils, include the following:

- Conservation tillage

Conservation tillage minimizes or eliminates manipulation of the soil for crop production; It includes the practice of mulch tillage, which leaves crop residues on the soil surface. These procedures generally reduce soil erosion, improve water use efficiency, and increase carbon concentrations in the topsoil. Conservation tillage can also reduce the amount of fossil fuel consumed by farm operations. It has been estimated to have the potential to sequester a significant amount of $\mathrm{CO}_{2}$

\section{- Cover cropping}

Cover cropping is the use of crops such as clover and small grains for protection and soil improvement between periods of regular crop production. Cover crops improve carbon sequestration by enhancing soil structure, and adding organic matter to the soil. 


\section{- Crop rotation}

It is a sequence of crops grown in regularly recurring succession on the same area of land. It mimics the diversity of natural ecosystems more closely than intensive mono-cropping practices. Varying the type of crops grown can increase the level of soil organic matter. However, effectiveness of crop rotating depends on the type of crops and crop rotation times.

Management for carbon sequestration affects other gases that influence climate such as atmospheric concentrations of nitrous oxide and methane. Changes in these gases must also be factored into management strategies for carbon storage. Besides giving due attention for carbon sequestration in soil it is also important to limit the emission of other non- $\mathrm{CO}_{2}$ greenhouse gases from the soil which significantly contributes for global temperature rise through different soil management practices like fertilizer management etc.

\subsection{Fertilizer Management}

Nitrogen fertilizer can increase soil organic matter because nitrogen is often limited in agroecosystems. However, the $\mathrm{CO}_{2}$ released from fossil fuel combustion during the production, transport and application of nitrogen fertilizer can reduce the net amount of carbon sequestered.

N Source Nitrate N sources may result in greater denitrification and leaching than ammonia-based sources of $\mathrm{N}$ (eg. Urea), if applied under cold, wet and waterlogged conditions, but could lose high amounts of ammonia gas if top-dressed under warmer and windy conditions, especially on alkaline soils. Urea is also currently the cheapest straight source of $\mathrm{N}$ and DAP the cheapest mixed source of $\mathrm{N}$.

Match crop demand only apply $\mathrm{N}$ when is actively growing and can utilize the $\mathrm{N}$ and only apply the highest recommended rates when no other limiting factors are restricting yield potential. Avoid excessive nitrogen fertilizer rates for actively growing crops, do not apply above 50 to $60 \mathrm{~kg} \mathrm{~N} \mathrm{ha}^{-1}$ in any single application and do not apply $\mathrm{N}$ closer than 21 (30 kg N ha ${ }^{-1}$ in spring) to 28 (50 kg N ha-1) days apart, as this will increase $\mathrm{N}$ losses dramatically. Warm and waterlogged soils condition application of $\mathrm{N}$ fertilizers Avoid high $\mathrm{N}$ rates on waterlogged soils, particularly if soil temperatures are high, as this will maximize denitrification losses.

Coated/ treated fertilizers There are a number of formulations and coatings that can be applied to $\mathrm{N}$ fertilisers that will eliminate nitrous oxide losses directly from fertilizer. These products do increase the unit cost of the $\mathrm{N}$ fertiliser and the producer will need weigh the costs against the likely reduction in $\mathrm{N}$ loss. However, these fertilisers are likely to become more commonplace with an increasingly emissions constrained future. Examples include:

Controlled-release A range of polymer-coated / impregnated fertilizer products are available, releasing their $\mathrm{N}$ according to the predicted crop growth pattern. Controlled Release Fertilizers are usually prills of fertilizer encapsulated in a polymer or oil-based coating. The polymer coating controls the rate of release by allowing the fertiliser to pass through the coating often controlled by the thickness or type of polymer used and soil conditions (often referred to as biodegradable resin-coated slow-release fertilisers or methylene-urea polymers).

Slow Release Fertilizers work by changing the chemical composition or mixing the fertiliser to reducing its solubility. The key difference between controlled and slow release technologies may appear semantics, but are used strongly in marketing in that one product actual controls the release pattern and timing, while the other is merely a constant, but slower release of the nutrient.

Nitrification inhibitors: Nitrification inhibitors can be provided as a coating or spray that inhibits the conversion of ammonia to nitrate in the soil, thus reducing the chance of both nitrate leaching and denitrification loss. Applied as a spray, nitrification inhibitors can also be effective in reducing nitrous oxide emissions from animal urine by $60-90 \%$, with pasture yield increases of $0-36 \%$, depending on sol type and climate. A commercially available spray is available in Australia and New Zealand for reducing nitrous oxide losses from urine deposition on pastures. Urease inhibitor-coated fertilizer products are also readily available for situations where high ammonia loss from urea may be otherwise unavoidable.

\subsection{Soil management}

Irrigation and drainage: Irrigation aims to maintain the soil above wilting point and below field capacity, the soil moisture zone that maximizes nitrous oxide loss. Poorly drained soils are anaerobic thus promoting denitrification of soil nitrate. In both cases, if soil nitrate is in excess of crop growth, nitrous oxide loss can be high.

Soil compaction: The more compact soils, the more anaerobic it becomes, leading to higher nitrous oxide loss through denitrification. Soil is commonly compacted through wheel traffic in cropping systems and through treading from animal hooves in grazing systems.

\section{Impacts of sequestering carbon in soil}

Carbon sequestration and an increase in soil organic matter will have a direct positive impact on soil quality and fertility, on the environment, and on the resilience and sustainability of agriculture, SOM has essential biological, physical and chemical functions in soils, OM content is generally considered one of the primary indicators of soil 
quality, both for agriculture and for environmental functions. An increase in carbon sequestration causes an increase in the operational biodiversity and more effective soil biological functioning, which is normally very low in most agricultural soils. Above ground biodiversity in cropping systems (vegetation, birds etc.) also depends on the type of management. All the consequences and benefits of this approach should be appreciated with regard to the sustainability of agriculture even in respect of gene reservoirs and the biological control of pests.

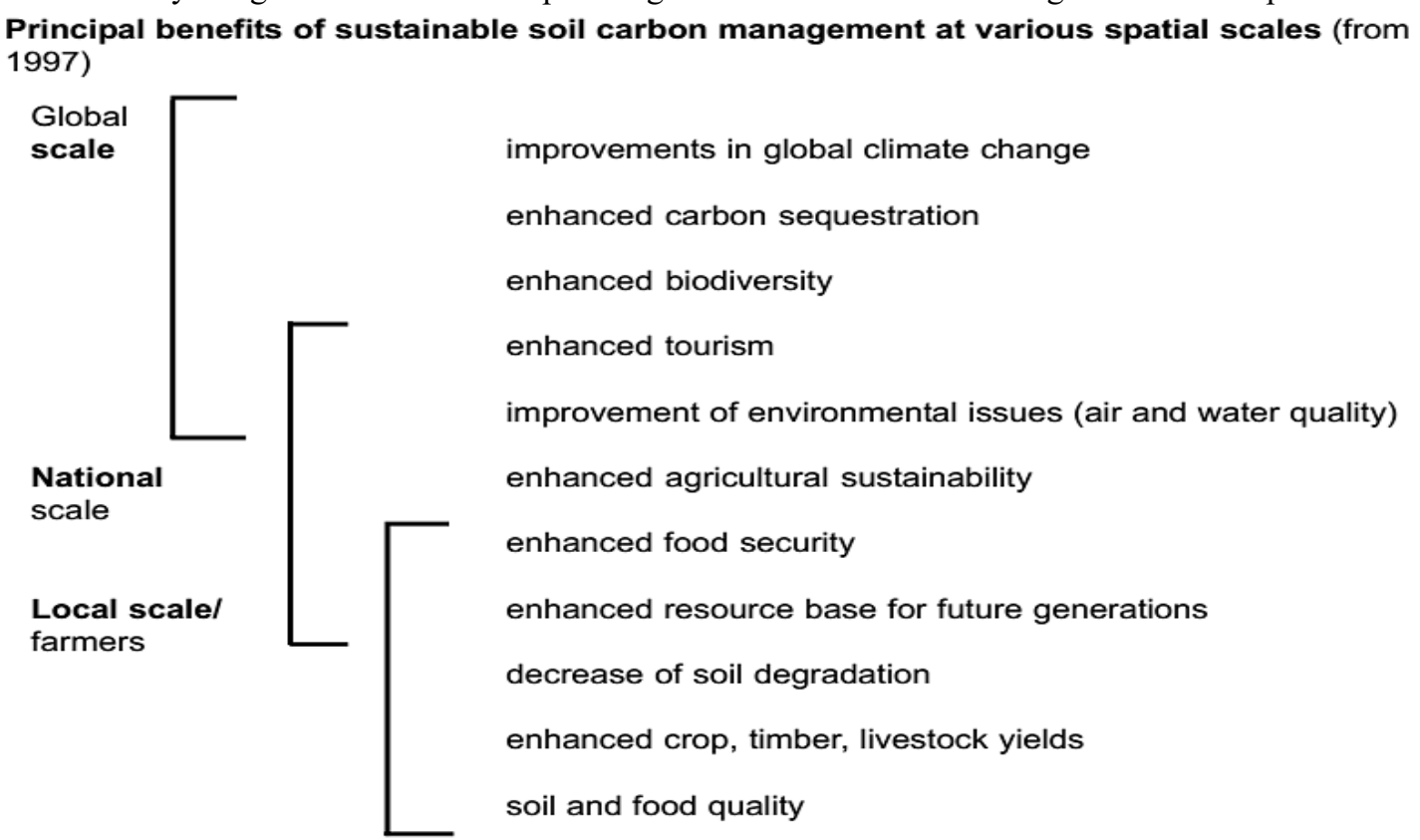

Figure 3. Impacts created at different levels of hierarchy by sequestering carbon in soil.

Carbon sequestration in agricultural soils counteracts desertification process through the role of increased soil organic matter in structural stability (resistance to both wind and water erosion) and water retention, and the essential role of soil surface cover by plant, plant debris or mulch in preventing erosion and increasing water conservation. OM, which increases the soil quality, also protects through fixation of pollutants (both organic, such as pesticides, and mineral, such as heavy metals or aluminum) with, in general, a decrease in their toxicity.

Air quality is mainly concerned with the decrease in atmospheric $\mathrm{CO}_{2}$ concentration, but attention has to be given to other greenhouse gases, particularly methane and nitrous oxide $\left(\mathrm{CH}_{4}\right.$ and $\left.\mathrm{N}_{2} \mathrm{O}\right)$. The main soil factor controlling their genesis is anaerobiosis (soil reduction), which is generally linked with hydromorphy. When pastures or rangelands are increased, the methane emission by cattle has to be taken into account. In some environments and depending on climatic conditions (humid area) or soil properties (high clay content), $\mathrm{N}_{2} \mathrm{O}$ can be formed. Hence careful balance of the different gas emissions has to be made. Wetland rice culture represents the most complex system in relation to carbon sequestration. If $\mathrm{OM}$ is accumulated in wetland soil, $\mathrm{CH}_{4}$ is also formed. The greenhouse effect of methane is far greater than that of $\mathrm{CO}_{2}$. The usual strategy for preventing $\mathrm{CH}_{4}$ formation is to decrease the duration of waterlogging, so that $\mathrm{OM}$ will be less protected from mineralization and $\mathrm{CO}_{2}$ and $\mathrm{N}_{2} \mathrm{O}$ or $\mathrm{NH}_{4}$ can be emitted. In view of these various effects, it seems very difficult for the moment to jointly manage wetland rice production and carbon sequestration. Recent developments of conservation agriculture in rice-wheat systems are very positive, however: rice yields can be maintained or improved without water saturation, puddling or soil reduction and with major water savings in the rice growing period. This new approach has been validated by farmers on several thousand ha in countries including India and Brazil.

Natural wetlands have similar anaerobic conditions with a smaller $\mathrm{CH}_{4}$ emission than wetland rice fields and a greater potential for $\mathrm{C}$ sequestration, which can take the form of peat formation. They also have other important environmental advantages, so they should be protected; it would not be realistic to hope for a rapid increase. Water quality is also improved by the decrease of erosion and runoff of water and pollutants. In the specific case of conservation tillage, strong OM mineralization with nitrate formation is avoided or minimized as well.

Changes in land use and land management also have an important effect on the partition of precipitation between runoff and storage or infiltration, with an increase of the latter under grassland, forest and conservation tillage with soil cover. Soil cover will prevent erosion. Hence, even if some runoff still occurs the water will be free of particles with associated pollutants (mineral trace elements, $\mathrm{PO}_{4}$ ). Off-site pollution by soluble products will decrease also in relation with lesser runoff. This is one of the bases of the eco-conditionality in the US Farm bill since 1996. With such changes in agricultural practices the challenge for the water quality can be met. Once the changes have taken place over large areas the frequency and severity of floods will decrease as well. The overall effect of increasing OM in soil is an improvement of soils buffer capacity and resilience to different kinds 
of degradation or stress.

\section{Summary and Conclusion}

Currently climatic change become major concern of the world from which all nations will suffer with several misbalancing impact of ecosystem resulting natural disasters unpredictable rain fall pattern and drought occurrence which majorly affects developing countries like Ethiopia. Their agriculture majorly dependent on the rain fed system. So, climate change adaptation and mitigation approaches were getting due attention to tackle those impacts to the future plan from those multiple approaches of climatic change mitigations methods eliminating greenhouse gas effect specially $\mathrm{CO}_{2}$ through carbon sequestration specially in soil plays a major role. Anthropogenic activities can affect soil carbon stock in both negative and positive ways so by improving those agricultural activities specially soil management practices in such a way that improve their carbon storage as a sink to minimize atmospheric $\mathrm{CO}_{2}$ and improve the functionality of soil for agricultural and ecosystem use.

The degradation of soils from unsustainable agriculture and other development has released billions of tons of carbon into the atmosphere. But new research shows how effective land restoration could play a major role in sequestering $\mathrm{CO}_{\mathrm{m}}$ and slowing climate change.

Conservation tillage and NT systems along with crop rotation have been implemented to maximize soil C storage or SOC sequestration.

Concerning of greenhouse gas emission other than $\mathrm{CO}_{2}$, soil management practices play a major role through avoiding compaction and drainage problem to reduce methane and nitrous oxide emission (denitrification) under anaerobic condition to the atmosphere.

On paddy production using intermittent or submerged irrigation known to reduce greenhouse gas emission by creating water logged condition only in the critical and sensitive stage of the paddy crop.

Fertilizer management like proper timing and rate of application to a level where the crops can optimally use it's for growth is critical to reduce the pollution effect to the environment as a result of losses to inappropriate places.

Storing carbon in soil as a form of SOC not only improves the carbon fixation from the atmosphere but also it enhances good soil quality for the soil itself by improving its ecological balancing functionality.

\section{Reference}

Al-Kaisi, M., (2008), "Impact of tillage and crop rotation systems on soil carbon sequestration", Iowa State University - University Extension.

Andreux, F. and Choné, T. (1993), "Dynamics of soil organic matter in the Amazon ecosystem and after deforestation: basis for efficient agricultural management", $51 \mathrm{pp}$. Centre National de la Recherche Scientifique, Nancy.

Arrouays, D. Deslais, W. Daroussin, J. Balesdent, J. Gailland, J. Dupoucy, J L., Nys, C., Badeau, V. and Belkacem, S. (1999), "Stocks de carbone dans les sols de France: quelles estimations?" C.R. Acad. Agric. Fr. 85. 278292.

Baker, J.M. Ochsner, T.E., Venterea, R.T. and Griffis, T.J. (2007), "Tillage and soil carbon sequestration-what do we really know?" Agric. Ecosyst. Environ. 118:1-5. doi: 10.1016/j.agee. 2016.05.014.

Batjes, N.H. (1996), "Total carbon and nitrogen in the soils of the world". Eur. J. Soil Sci. 47: 151-163.

Benbi, D.K. and Brar, J.S. (2009). "A 25-year record of carbon sequestration and soil properties in intensive agriculture”, Agron. Sustain. Dev. 29:257-265.

Benbi, D.K. and Chand M. (2007), "Quantifying the effect of soil organic matter on indigenous soil N supply and wheat productivity in semiarid sub-tropical India", Nutr. Cycl. Agroecosys. 79:103-112.

Benbi, D.K. and Senapati, N. (2010), "Soil aggregation and carbon and nitrogen stabilization in relation to residue and manure application in rice-wheat systems in northwest India". Nutr. Cycl. Agroecosys. 87:233-247.

Bockman, O.C. and Olfs, H.W. (1998), "Fertilizers, agronomy, and $\mathrm{N}_{2} \mathrm{O}$. Nutrient Cycling in Agroecosystems", Dordrecht, v. 52, p. 165-170.

Brasil. (2010), Ministério da Ciênciae Tecnologia. Coordenação Geral de Mudanças Globais do Clima. Segunda comunicação nacional do Brasil à convenção-quadro das Nações Unidas sobre mudança do clima. Brasília, DF: Ministério da Ciência e Tecnologia,

Bremner J.M. (1997), "Sources of nitrous oxide in soils", Nutrient Cycling in Agroecosystems, Dordrecht, v. 49, n. $1-3$, p. $7-16$.

Caroline Schimidt, Sebastian Behrens and Andreas Kappler, (2010), "Ecosystem functioning from a geomicrobiological perspective-a conceptual frame work for biogeochemical iron cycling", University of Tuebingen, Germany. CSIRO publishing environ. Chem. 7: 399-405.

Cerri, C.C. et al. (2009), "Brazilian greenhouse gas emissions: the importance of agriculture and livestock", Scientia Agricola, Piracicaba. 66 (6): 831-843.

Christopher, S., Lal, R. and Mishra, U. (2009), "Regional study of no till effects on carbon sequestration in 
Midwestern", U.S. Soil Soc. Am. J. 73:207-216.

Daniel Kane. (2015), Carbon Sequestration Potential on Agricultural Lands: A Review of Current Science and Available Practices. In association with: National Sustainable Agriculture Coalition Breakthrough Strategies and Solutions, LLC.

Denman, K. L. et al. (2007), "Couplings between changes in the climate system and biogeochemistry". In: Solomon S., et al. (Eds.). Climate change 2007: "the physical science basis", Cambridge: Cambridge University Press, p. 499-588.

Diana Signor, Carlos Eduardo, Pellegrino Cerri. 2013. Nitrous oxide emissions in agricultural soils: a review. Embrapa, Brazil. v. 43, n. 3, p. 322-338.

Dinesh, K. Benbi (2013) Greenhouse Gas Emissions from Agricultural Soils: Sources and Mitigation Potential, Journal of Crop Improvement, 27:6, 752-772.

Dupouey, J.L. Siguand, G. Bateau, V. Thimonier, A. Dhole, J.F., Nepveu G. Bergé L. Augusto, L. Belkacem, S. and Nys, C. (1999), "Stocks et flux de carbone dans les forêts françaises". C.R. Acad. Agric. Fr 85 (6): 293310.

EPA (Environmental Protection Agency), (2006), "Global Anthropogenic Non- $\mathrm{CO}_{2}$ Greenhouse Gas Emissions": 19902020. EPA 430-R-06-003.

Eugster Werner and Nina Buchmann, (2011), "Greenhouse gas emissions from agricultural soils", a global perspective Institute of Agricultural Sciences, ETH Zürich. DAGRIL food system.

Falkowski, P., Scholes ,R.J. Boyle, E. Canadell, J. Canfield, D. Elser J., Gruber N., Hibbard K., Hogberg P., Linder S, Mackenzie F T., Moore III B., Pedersen T. Rosenthal Y., Seitzinger S., Smetacek V. and Steffen, W. 2000. The global carbon cycle: A test of our knowledge of Earth as a system. Science 290:291-29.

FAO/IFAD. 1999. Prevention of land degradation, enhancement of carbon sequestration and conservation of biodiversity through land use change and sustainable land management with a focus on Latin America and the Caribbean. World Soil Resources Reports 86.

FAO. 2001. Soil Carbon Sequestration for Improved Land Management. World Soil Resources Reports 96. Rome. $75 \mathrm{pp}$.

Follett R F. 2001. Soil management concepts and carbon sequestration in cropland soils. Soil Till. Res. 61:77-92.

Green, Timothy R.; Taniguchi, Makoto; Kooi, Henk; Gurdak, Jason J.; Allen, Diana M.; Hiscock, Kevin M.; Treidel, Holger; and Aureli, Alice, "Beneath the surface of global change: Impacts of climate change on groundwater" (2011). Publications from USDA-ARS/ UNL Faculty. 851.

Greenland D J. 1994. Long term cropping experiments in developing countries: The need, the history and the future. In Leigh R A. and Johnston, A E. eds. Long-term experiments in Agricultural and Ecological Sciences. p 187-209. CAB International, Wallingford 428pp.

Groffman P M. et al. 1996. New approaches to modeling denitrification. Biogeochemistry, Dordrecht, v. 93, n. 12, p. 1-5.

Hayatsu M., Tago K., Saito M. 2008. Various players in the nitrogen cycle: diversity and functions of the microorganisms involved in nitrification and denitrification. Soil Science and Plant Nutrition, Tokyo, v. 54, n. 1, p. 33-45.

Houghton R A. 1995. Changes in the storage of terrestrial carbon since 1850, In: (eds). Soils and Global Change. Lal, R., Kimble, J., Levine, E., Stewart, B.A. CRC \& Lewis Publishers, Boca Raton, FL. p. 45-65.

Howard P J., Loveland P J., Bradley R I., Dry F T., Howard D M. and Howard D C. 1995. The carbon content of soil and its geographical distribution in Great Britain. Soil Use and Management. 11: 9-15.

IPCC. 2007. Climate Change 2007. The Fourth Assessment Report. The Physical Science Basis. Cambridge, United Kingdom, Cambridge University Press.

Johnson, J.M.F., D.C. Reicosky, R.R. Allmaras, T.J. Sauer, R.T. Venterea, and C.J. Dell. 2005. Greenhouse gas contributions and mitigation potential of agriculture in the central USA. Soil Tillage Res. 83:73-94.

Kern J S. 1994. Spatial patterns of soil organic carbon in the contiguous United States. Soil Sci. Soc. Am. J. 58:439-455.

Kumar, S., A. Kadono, R. Lal, and W. Dick. 2012. Long-term no-till impacts on organic carbon and properties of two contrasting soils and corn yields in Ohio. Soil Sci. Soc. Am. J. 76:798-809.

Lal, R. 2009. Challenges and opportunities in soil organic matter research. Eur. J. Soil Sci. 60:1-12 10.111/j.13652389.2017.01114. $\mathrm{x}$.

Le Treut H., Somerville R., Cubasch U., Ding Y., Mauritzen C., Mokssit A., Peterson T., Prather M., 2007. Historical overview of climate change. In: Solomon S.et al., (Eds.), Climate Change 2007: The Physical Science Basis. Contribution of Working Group I to the Fourth Assessment Report of The Intergovernmental Panel on Climate Change. Cambridge University Press, Cambridge, United Kingdom, and New York, NY, USA.

Ogle, S.M., A. Swan, and K. Paustian. (2012), "No-till management impacts on crop productivity, carbon input and soil carbon sequestration”, Agric. Ecosyst. Environ. 149:37-49. 
Olson, K.R. 2010. Impacts of tillage, slope and erosion on soil organic carbon retention. Soil Sci. 175: $562-567$.

Olson, K.R. 2013. Soil organic carbon sequestration, storage, retention and loss in U.S. croplands: Issues paper for protocol development. Geoderma 195-196: 201-206.

Orr, J.C. et al. 2001. Estimates of anthropogenic carbon uptake from four three-dimensional global ocean models. Global Biogeochem. Cycles 15:43-60.

Sanchez P A., Buresh R J. and Leakey R B. 1999. Trees, soils and food security. Philosophical Transactions of the Royal Society of London, Series B 353: 949-961.

Schlesinger W H. 1999. Carbon sequestration in soils. Science 284: 2095.

Schneider S., Towprayoon M., Wattenbach and J. Smith. 2008. Greenhouse gas mitigation in agriculture. Philos. Trans. R. Soc. B Biol. Sci. 363(1492): 789-813.

Sombroek W G., Nachtergaele F O. and Hebel A. 1993. Amounts, dynamics and sequestering of carbon in tropical and subtropical soils. Ambio 22: 417-426.

Stevenson F J. 1982. Humus chemistry. Genesis, composition, reactions. John Wiley and Sons.

Sundermeier A., Reeder R. and Lal. R. 2005. Soil carbon sequestration fundamentals. Rep. No. OSU Factsheet AEX-510-05. OSUE, Columbus, OH. Available online at http://ohioline.osu.edu/aex-fact/0510.html (verified 4 Mar. 2017).

Van Oost K., Quine T A., Govers G., McGregor A. and B. Slattery. 2007. The impact of agricultural soil erosion on the global carbon cycle. Science 318:626-629.

Vanden Bygaart, Gregorich E G., and Angers D.A. 2003. Influence of agricultural management on soil organic carbon: A compendium and assessment of Canadian studies. Can. J. Soil Sci. 83:363-380.

West T O. and Post W M. (2002), Soil organic carbon sequestration rates by tillage and crop rotation: A global data analysis. Soil Sci. Soc. Am. J. 66:1930-1946.

Wilks D S. and Wilby R L. (1999), The weather generation game: a review of stochastic weather models. Prog. Phys. Geogr. 23: 329-357.

World Bank. (2015), "Agricultural nitrous oxide emissions (\% of total)", Available at http://data.worldbank.org/indicator/EN.ATM.NOXE.AG.ZS/countries/1W?display=grap $h \quad$ (verified 1 October 2017). 